\title{
MIDDLE-CLASS ENTREPRENEURS AND INADEQUATE PROSPECTS FOR SOCIAL MOBILITY THROUGH ENTREPRENEURSHIP IN COLOMBIA*
}

\author{
Paula Mejía ${ }^{* *}$ \\ MARCEla Meléndez ${ }^{* * *}$
}

\begin{abstract}
This paper explores whether Colombia's middle class is a cradle of entrepreneurship that drives innovation and business growth and fosters social mobility. Microeconomic data are used to characterize entrepreneurs by income group and business characteristics. While entrepreneurs appear to enjoy more income mobility than the average worker, it is not clear whether this is true for middle-class entrepreneurs in particular or if it is a result of entrepreneurship. Nor is there evidence that middle-class entrepreneurs' activity boosts economic growth. Instead, the findings suggest that businesses run by these entrepreneurs are characterized by low productivity.
\end{abstract}

JEL classification: I310; L26; O12.

Keywords: Middle class, social mobility, entrepreneurship, survey data, Colombia

\section{INTRODUCTION}

"If the middle class matters for growth, it is probably not because of its entrepreneurial spirit," Banerjee and Duflo (2008) conclude in their overview examining the middle classes around the world. Middleclass entrepreneurs ${ }^{1}$ run businesses mostly because they cannot find appropriate salaried jobs and their business investments are very similar to those of the poor. The main difference is that they are less likely to be involved in farming businesses when they live in rural areas. Working on their own, middle-class entrepreneurs are able to earn about the same income as they would if they were employed, assuming they could find a salaried job, while working longer but less

\footnotetext{
* We are grateful to Eduardo Lora and Francesca Castellani for their feedback on previous versions of the paper and to participants in the "Strengthening Mobility and Entrepreneurship: A Case for the Middle Classes" IDB workshops held in Washington, D.C. and Santiago, Chile in 2011. We would also like to thank Edgar Castro who helped us give the paper its final shape.

** ECON ESTUDIO, Carrera 7 No. 79B-15, Of. 401, Bogotá, Colombia. Email: marcela.melendez@ econestudio.com.

*** 1605 Sansom St., Apt. 210, Philadelphia, PA, U.S.A. Email: paula.mejia.wg16@wharton.upenn.edu.

1. Entrepreneurs are defined here as business owners with employees.
} 
intensive hours. Banerjee and Duflo depict their businesses more as means of sustenance than as "engines of growth."

Despite the low profits of their businesses, middle-class entrepreneurs enjoy high returns to capital investments. This fact, combined with evidence of high borrowing costs, suggests that businesses owned by middle-class entrepreneurs are undercapitalized because of poor access to credit. Why these businesses share this characteristic with businesses owned by poor entrepreneurs when the middle classes are typically less credit-constrained is not clear. The lack of savings to grow their businesses is also puzzling because the middle class accumulates other assets and is more likely to have savings than the poor.

Banerjee and Duflo's analysis draws from information on households at the two extremes of what they call the middle class: households with daily per capita expenditures valued at purchasing power parity between $\$ 2$ and $\$ 4$ and households between $\$ 6$ and $\$ 10 .^{2}$

Consistent with these findings and using data from the Panel Study of Income Dynamics in the United States, Hurst and Lusardi (2003) find that the relationship between initial wealth and the propensity to start a business is highly nonlinear, with a positive relationship only for households in the top $5 \%$ of the wealth distribution. While there is a substantial amount of literature documenting a positive relationship between initial wealth and business entry, ${ }^{3}$ these authors interpret their finding that this relationship does not hold for most of the population as casting doubt on the importance of liquidity constraints in deterring business formation (in the United States).

In related research, Ardagna and Lusardi (2008) explore the role of individual characteristics as potential explanations for international differences in entrepreneurship in a cross-country setting using micro data. They distinguish between entrepreneurs driven by an interest to pursue a business opportunity ("opportunity entrepreneurs") and what they call "remedial" entrepreneurs: entrepreneurs whose businesses are more a means of sustenance, like the type portrayed by Banerjee and Duflo when referring to middle-class entrepreneurs. Ardagna and Lusardi find that opportunity entrepreneurs are slightly younger, more likely to be male, more likely to have higher education levels, and

2. All amounts are in U.S. dollars.

3. Evans and Jovanovic (1989); Evans and Leighton (1989); and Gentry and Hubbard (2001), among others. 
more likely to have higher incomes. These results hold across country groups categorized by income and world regions.

The question of whether the middle class is a cradle for entrepreneurship capable of driving innovation and business growth and fostering social mobility through the pursue of business opportunities, or conversely, if the middle class is not particularly entrepreneurial-as the literature mentioned above suggests-is ultimately an empirical question, and the answer may be partly dependent on particular country characteristics.

This paper explores the case of Colombia using microeconomic data to characterize entrepreneurs ${ }^{4}$ by income group in terms of both their household and individual characteristics, and in terms of the characteristics of the businesses in which they participate. It also investigates whether middle-class entrepreneurs have more social mobility than the average worker using pseudo-panel techniques.

We find that entrepreneurship is scarce but it is more frequent in the upper classes. Middle-class entrepreneurs are better off than middleclass employees of similar characteristics, on average, but they are very different from upper-class entrepreneurs in terms of educational attainment and the size of the businesses they run. While in general entrepreneurs appear to enjoy greater income mobility than the average worker, we are unable to establish if this is true for middle-class entrepreneurs in particular or if this mobility is a result of entrepreneurship more generally. Our income mobility analysis, moreover, is biased towards successful entrepreneurs, since we do not observe individuals before they become entrepreneurs or individuals whose enterprises fail. We are also unable to provide evidence supporting the hypothesis that their activity is an engine for economic growth; however, our findings suggest that the types of businesses they run have low productivity. We conclude that there is nothing in particular about Colombian middle-class entrepreneurs suggesting that policies to promote entrepreneurship among this segment of the population would be desirable.

\section{ENTREPRENEURSHIP IN THE MIDDLE CLASS}

We characterize Colombian middle-class entrepreneurs using the 2010 Living Standards Survey (LSS) from DANE, Colombia's national statistics office. This survey is nationally representative of urban and 
rural areas and for nine regions. It collects information about both individual and household characteristics, including detailed information about their expenditures that allows us to categorize households (and entrepreneurs) by expenditures per capita.

For the purpose of this research, we define entrepreneurs as individuals who identify themselves in the survey as employers. ${ }^{5}$ Unfortunately we are not able to identify new entrepreneurs because we do not follow individuals over time; we only know the current status reported by individuals in the surveys. To assign entrepreneurs and other workers to income groups, we use the thresholds proposed by the 2011 World Bank's Flagship Report on the Middle Classes, which defines middleclass households as those with daily per capita expenditures between $\$ 10$ and $\$ 50$ (2005 purchasing power parity). The resulting worker types by income group are shown in Table 1 .

We find there are relatively few entrepreneurs $(512,000$, compared to 7.66 million employed workers in 2010) and although in terms of absolute numbers entrepreneurs are concentrated in the middle class, as a share of total workers they are more prevalent in the upper class. Only $3.5 \%$ of the working population are entrepreneurs.

Female participation is much lower among entrepreneurs than among employed workers, and this holds true for all social classes (25 versus $41 \%$ in the lower class; 31 versus $50 \%$ in the middle class; and 26 versus $52 \%$ in the upper class). Entrepreneurs are older than their employed counterparts, on average.

Entrepreneurs in all classes are better off than employed workers in terms of labor income. The mean monthly income of a middle-class entrepreneur is $\$ 1,690$, well above the $\$ 1,054$ figure for a middle-class employee. The difference is not as great in the other two classes $(\$ 674$ for entrepreneurs versus $\$ 476$ for employees in the lower class, and $\$ 3,411$ for entrepreneurs versus $\$ 3,268$ for employees in the upper class), but the advantage remains. Mean labor income is broken down further by individual characteristics (gender, age, education, activity sector and business size). On average, females have lower labor incomes. Labor income increases with age and education for both entrepreneurs and employees, but entrepreneurs do better than employees with similar characteristics. This pattern holds for all sectors of activity and for all 
Table 1. Working population by type and class

\begin{tabular}{|c|c|c|c|c|c|}
\hline \multirow[b]{2}{*}{ Worker type } & \multirow[b]{2}{*}{ Class group } & \multirow[b]{2}{*}{ Number } & \multicolumn{3}{|c|}{ Percentage } \\
\hline & & & $\begin{array}{l}\text { of total } \\
\text { workers }\end{array}$ & $\begin{array}{l}\text { of worker } \\
\text { type }\end{array}$ & of class \\
\hline \multirow{4}{*}{ Total workers } & Lower class & $9,759,451$ & & 66.5 & 100.0 \\
\hline & Middle class & $4,466,028$ & & 30.4 & 100.0 \\
\hline & Upper class & 460,203 & & 3.1 & 100.0 \\
\hline & Total workers & $14,685,682$ & 100.0 & & \\
\hline \multirow{4}{*}{ Entrepreneurs } & Lower class & 175,694 & & 34.4 & 1.8 \\
\hline & Middle class & 236,857 & & 46.3 & 5.3 \\
\hline & Upper class & 98,575 & & 19.3 & 21.4 \\
\hline & Total entrepreneurs & 511,126 & 3.5 & & \\
\hline \multirow{4}{*}{ Employees } & Lower class & $4,750,020$ & & 62.0 & 48.7 \\
\hline & Middle class & $2,648,532$ & & 34.6 & 59.3 \\
\hline & Upper class & 261,238 & & 3.4 & 56.8 \\
\hline & Total employees & $7,659,790$ & 52.2 & & \\
\hline \multirow{4}{*}{$\begin{array}{l}\text { Self-employed } \\
\text { workers }\end{array}$} & Lower class & $4,833,737$ & & 74.2 & 49.5 \\
\hline & Middle class & $1,580,639$ & & 24.3 & 35.4 \\
\hline & Upper class & 100,390 & & 1.5 & 21.8 \\
\hline & Total self-employed workers & $6,514,766$ & 44.4 & & \\
\hline
\end{tabular}

business sizes with the exception of upper-class individuals working in agriculture, mining or manufacturing, who do better when they are employed than as entrepreneurs. Average labor incomes increase by business size for all individuals.

Unsurprisingly, the upper class has the largest concentration of individuals with the highest levels of educational attainment (79\% of upper-class entrepreneurs and $77 \%$ of upper-class employees completed technical or higher education). Among middle-class entrepreneurs, $10 \%$ have primary education or less; $41 \%$ completed only high school; and $42 \%$ have a technical education or higher. A large share of individuals work under informal labor arrangements. ${ }^{6}$ While this is more common among

6. An informal labor arrangement is defined as one in which the worker has access to health coverage through the subsidized regime instead of making the monthly contribution to the health insurance system as mandated by law in Colombia. 
entrepreneurs (59\% of lower-class entrepreneurs and $19 \%$ of middle-class entrepreneurs fall in this category), the percentages are also relatively large for employees (where the corresponding shares are 38 and 10\%).

Finally, households of lower-class and middle-class entrepreneurs have higher per capita expenditure levels than households of lower-class and middle-class employees ( $\$ 178$ versus $\$ 163$ in the lower class, and $\$ 640$ versus $\$ 593$ in the middle class). Upper-class entrepreneurs' households are on average less well-off than the households of upperclass employees, but the median expenditure per capita is $\$ 200$ higher for upper-class entrepreneurs than upper-class employees ${ }^{7}$.

\section{Choosing TO BE AN ENTREPRENEUR}

To explore the choice to become an entrepreneur, we use a multinomial probit model that is estimated over all individuals 25 to 65 years old who report labor income or report being unemployed (with unemployment as the base category) in the Living Standards Surveys of 1997, 2003, and 2008. Because we do not observe each worker over time, we cannot account in this exercise for their "mobility" across work types (i.e., we cannot tell whether an entrepreneur started out as an employee or as a self-employed worker). Although the model has this limitation, it nevertheless provides interesting information about characteristics that set entrepreneurs apart from other types of workers.

As before, our sample is restricted to individuals in the urban areas. Using this specification, we estimate the probabilities of being an entrepreneur, an employed worker, or a self-employed worker ${ }^{8}$ and compare the relative importance of each variable as a determinant of the alternatives. The model explains the probability that an individual chooses to be an entrepreneur as a function of (a set of) individual and household characteristics. ${ }^{9}$

Table 2 shows the corresponding summary statistics and estimation results are presented in Table 3. From this model, we learn that the probability of being an entrepreneur relative to that of being employed, self-employed, or unemployed is 2.8 percentage points lower when the worker is a female; 0.1 percentage points higher for each additional

7. All differences reported are significant at least at the $10 \%$ level.

8. A self-employed worker is defined as a person who works independently on his or her own and has no paid employees.

9. The model includes time dummies to control for the macroeconomic cycle in the estimation. 
year of age; 0.2 percentage points higher for each additional year of schooling, increasing with the parents maximum level of education; 1.5 percentage points lower for individuals born in municipalities of more than 500,000 inhabitants; 2.6 percentage points higher if the individual is a head of household; and 2.0 percentage points higher if the individual is the spouse of the head of household.

Table 2. Summary statistics for multinomial probit model

\begin{tabular}{|c|c|c|c|c|c|}
\hline Variable & Obs. & Mean & Std. dev. & Min & $\operatorname{Max}$ \\
\hline Employee & 30,806 & 0.509 & 0.500 & 0 & 1 \\
\hline Entrepreneur & 30,806 & 0.046 & 0.210 & 0 & 1 \\
\hline Self-employed & 30,806 & 0.436 & 0.496 & 0 & 1 \\
\hline Unemployed & 30,806 & 0.021 & 0.143 & 0 & 1 \\
\hline Female & 30,806 & 0.450 & 0.497 & 0 & 1 \\
\hline Age & 30,806 & 43.199 & 8.174 & 25 & 65 \\
\hline Years of schooling & 30,806 & 8.431 & 4.794 & 0 & 18 \\
\hline \multicolumn{6}{|c|}{ Parents' schooling attainment: } \\
\hline No education & 30,806 & 0.467 & 0.499 & 0 & 1 \\
\hline Elementary & 30,806 & 0.377 & 0.485 & 0 & 1 \\
\hline High school & 30,806 & 0.090 & 0.286 & 0 & 1 \\
\hline Technical or higher & 30,806 & 0.066 & 0.249 & 0 & 1 \\
\hline \multicolumn{6}{|c|}{ Municipality of birth by size: } \\
\hline $25,000-50,000$ & 30,806 & 0.508 & 0.500 & 0 & 1 \\
\hline $50,000-100,000$ & 30,806 & 0.094 & 0.292 & 0 & 1 \\
\hline $100,000-500,000$ & 30,806 & 0.142 & 0.350 & 0 & 1 \\
\hline More than 500,000 & 30,806 & 0.256 & 0.436 & 0 & 1 \\
\hline Household head & 30,806 & 0.647 & 0.478 & 0 & 1 \\
\hline Spouse & 30,806 & 0.244 & 0.430 & 0 & 1 \\
\hline Average age of household members & 30,806 & 31.179 & 11.012 & 8 & 77 \\
\hline Number of household members & 30,806 & 3.995 & 1.832 & 1 & 20 \\
\hline
\end{tabular}

The model also shows that individual and household characteristics affect the probability of being an entrepreneur and the probability of being employed but in opposite directions. For example, the probability of being an employed worker is 5.0 percentage points higher if the individual is a female and 6.7 percentage points lower if the individual 


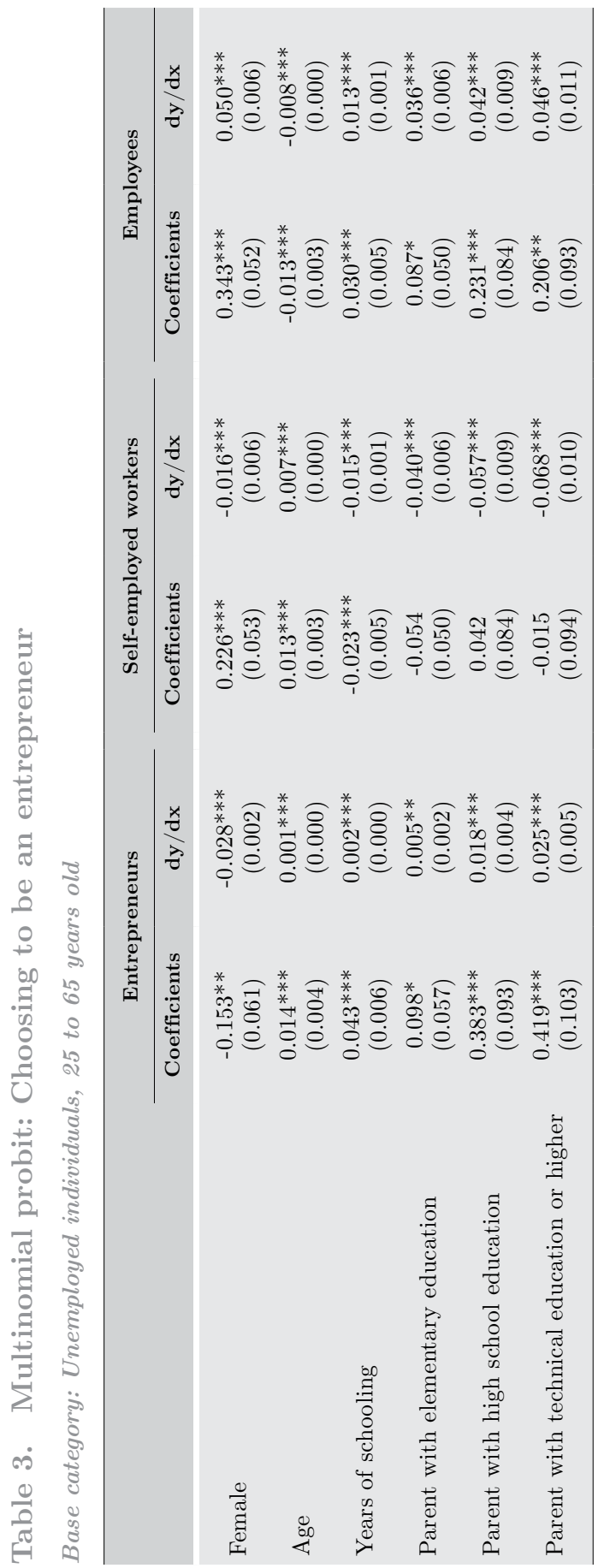




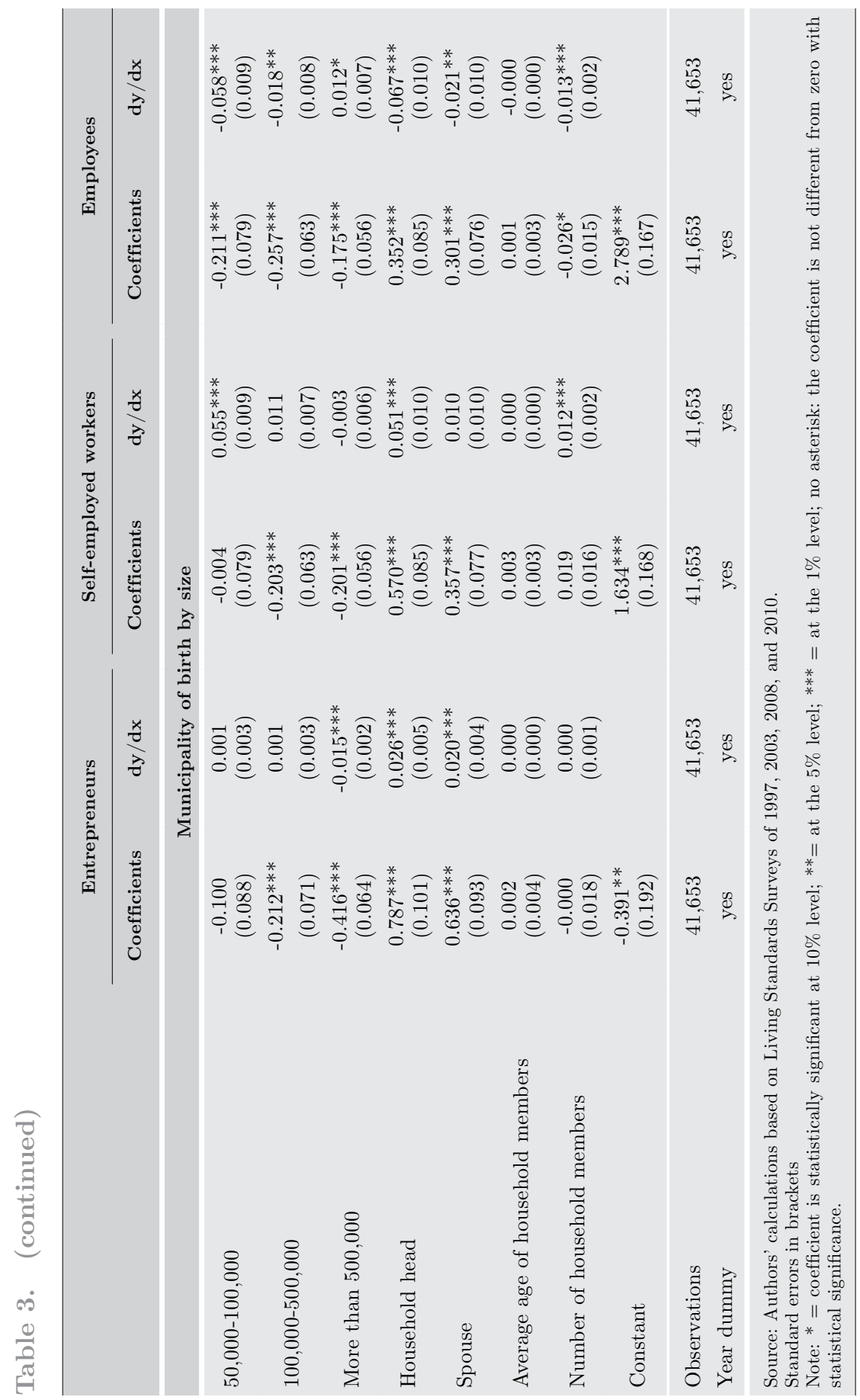


is a household head. Also, the probability of being employed is higher for individuals with more educated parents. Years of schooling have a larger (positive) effect on the probability of being employed than on the probability of being an entrepreneur.

The multinomial probit model confirms that self-employment is an occupational choice of individuals whose characteristics are different than those of both employees and entrepreneurs, on average. Age, for instance, is associated with a higher probability of being self-employed of 0.7 percentage points; years of schooling decrease the probability of being self-employed, as does parents' maximum educational attainment.

While the numbers obtained from this estimation should be interpreted with caution (for instance, the age variable may be capturing cohort effects, and/or the human capital variables may explain some household characteristics, so the size of the marginal effects estimated may lack the desirable precision), variations in the correlation of each variable to workers' choices contribute to setting entrepreneurs apart from other types of workers. This is the purpose of the exercise presented in this section, which should not be interpreted as exploring causality.

\section{INTER-GENERATIONAL SOCIAL MOBILITY}

We address the question of whether middle-class entrepreneurship is positively associated with social mobility, using microeconomic information about the educational level of individuals and their parents available from the 1997, 2003, 2008, and 2010 waves of DANE's Living Standards Survey ${ }^{10}$.

Table 4 makes a first attempt at answering this question by looking at transition matrices in which the educational attainment of parents is associated with that of their adult children. We have computed these transition matrices for each year for which the survey data is available, restricting the sample to the middle class and making separate calculations for entrepreneurs and employees.

For this purpose, individuals were assigned to one of four education categories according to the highest level completed (no education, primary, high school, and technical education or higher). We excluded individuals who report not knowing their parents' education level.

10. A careful process was conducted to homogenize household expenditures across surveys in order to make them comparable. 
The first striking impression that emerges from these matrices is that there is substantial mobility in Colombia, in the sense that children tend to do better than their most educated parent, at least in terms of years of schooling. The percentage of individuals with schooling equal to or below their parents' has dramatically fallen over time for individuals whose most educated parent had only completed elementary education or had no education at all. In 1997, 30\% of entrepreneurs whose parents had no education at all had ended up in the same education category, while the share in 2010 was $7 \%$ (the corresponding numbers for employees are $11 \%$ and $4 \%$ ). Similarly, in 1997, $40 \%$ of entrepreneurs whose most educated parent had completed only elementary school had completed elementary school or had no education; in 2010 this share had fallen to $24 \%$ (the corresponding numbers for employees are $26 \%$ and $19 \%$ ).

Also, the share of individuals whose parents had at most completed elementary school and who complete technical or higher education has grown remarkably over time. In the case of entrepreneurs, it jumped from $25 \%$ in 1997 to $56 \%$ in 2010 while for employees it grew from $43 \%$ in 1997 to $53 \%$ in 2010 .

In contrast with these results, which point toward higher upward mobility for entrepreneurs compared to those who became employees, educational attainment for the share of entrepreneurs with technical education or higher whose most educated parent is in the same education category appears to have fallen over time from $98 \%$ in 1997 to $91 \%$ in 2010. This result should be interpreted with caution because the number of entrepreneurs surveyed whose parents are in this education category is very small; for this reason, these statistics probably lack representativeness. ${ }^{11}$

In order to more properly assess to what extent parents' educational attainment explains an individual's education level, we estimate the following baseline regression:

$$
S_{i}=\alpha+\beta_{1} P S_{i}^{1}+\beta_{1} P S_{i}^{2}+\beta_{1} P S_{i}^{3}+\varepsilon
$$

where $S_{i}$ is individual $i$ 's educational attainment measured in years of education and $P S_{i}^{1}, P S_{i}^{2}$ and $P S_{i}^{3}$ are indicator variables that 
take a value equal to 1 when the individual's most educated parent completed elementary, high school, or technical or higher education, respectively; otherwise, its value is equal to 0 . We also estimate a version of this regression interacting parents' education variables with a dummy variable that is equal to 1 when the individual is a middleclass entrepreneur and zero otherwise, to capture any differential effect from this particular population group.

\section{Table 4. Transition matrices}

\section{(percentages)}

\begin{tabular}{|c|c|c|c|c|c|c|c|c|c|}
\hline & & \multicolumn{4}{|c|}{ Middle-class entrepreneurs } & \multicolumn{4}{|c|}{ Middle-class employees } \\
\hline & & 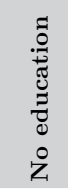 & 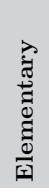 & $\begin{array}{l}\overrightarrow{0} \\
0 \\
0 \\
0 \\
0 \\
010 \\
010 \\
\ddot{10}\end{array}$ & 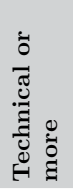 & 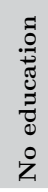 & 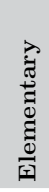 & 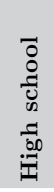 & 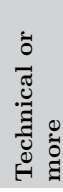 \\
\hline \multicolumn{10}{|c|}{1997} \\
\hline \multirow{4}{*}{ 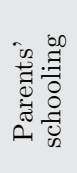 } & No education & 30 & 39 & 21 & 10 & 11 & 39 & 23 & 28 \\
\hline & Elementary & 3 & 37 & 36 & 25 & 1 & 25 & 31 & 43 \\
\hline & High school & 2 & 4 & 16 & 79 & 0 & 7 & 30 & 63 \\
\hline & Technical or more & 0 & 2 & 0 & 98 & 0 & 5 & 16 & 79 \\
\hline \multicolumn{10}{|c|}{2003} \\
\hline \multirow{4}{*}{ 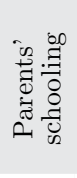 } & No education & 10 & 41 & 21 & 27 & 8 & 31 & 25 & 37 \\
\hline & Elementary & 1 & 28 & 32 & 39 & 2 & 16 & 31 & 52 \\
\hline & High school & 2 & 16 & 34 & 48 & 0 & 10 & 23 & 67 \\
\hline & Technical or more & 0 & 1 & 16 & 83 & 0 & 6 & 12 & 82 \\
\hline \multicolumn{10}{|c|}{2008} \\
\hline \multirow{4}{*}{ 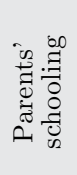 } & No education & 11 & 47 & 24 & 19 & 11 & 34 & 28 & 27 \\
\hline & Elementary & 0 & 33 & 33 & 34 & 2 & 23 & 31 & 44 \\
\hline & High school & 8 & 6 & 19 & 67 & 0 & 4 & 30 & 66 \\
\hline & Technical or more & 0 & 0 & 20 & 80 & 0 & 5 & 14 & 81 \\
\hline \multicolumn{10}{|c|}{2010} \\
\hline \multirow{4}{*}{ 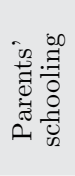 } & No education & 7 & 27 & 36 & 30 & 4 & 27 & 26 & 43 \\
\hline & Elementary & 1 & 23 & 21 & 56 & 2 & 17 & 28 & 53 \\
\hline & High school & 0 & 10 & 25 & 65 & 0 & 3 & 23 & 74 \\
\hline & Technical or more & 0 & 0 & 9 & 91 & 0 & 3 & 11 & 86 \\
\hline
\end{tabular}


The estimation results are presented in tables 5 and 6. In 2010, parents' elementary education accounted for 2.5 additional years of schooling; parent's high school education accounted for 4.2 additional years; and parent's technical or higher education accounted for 4.7 additional years. Thus, parents' education level is strongly associated with their children's. The magnitude of this positive correlation has decreased substantially over time however (for example, the coefficient for parents' technical education, which was equal to 6.6 in 1997, had fallen to 4.7 by 2010), indicating that individuals' education levels are decreasingly explained by their parents'.

\section{Table 5. Social mobility regressions 1}

\begin{tabular}{|c|c|c|c|c|c|}
\hline $\begin{array}{l}\text { Dependent variable: } \\
\text { Years of schooling }\end{array}$ & $\begin{array}{c}1997 \\
(1)\end{array}$ & $\begin{array}{c}2003 \\
(2)\end{array}$ & $\begin{array}{c}2008 \\
(3)\end{array}$ & $\begin{array}{c}2010 \\
(4)\end{array}$ & $\begin{array}{l}\text { Pooled } \\
\text { data } \\
(5)\end{array}$ \\
\hline \multicolumn{6}{|c|}{ Parents' schooling attainment: } \\
\hline Elementary & $\begin{array}{c}2.970 * * * \\
(0.122)\end{array}$ & $\begin{array}{c}2.957 * * * \\
(0.0795)\end{array}$ & $\begin{array}{c}3.021^{* * *} \\
(0.137)\end{array}$ & $\begin{array}{c}2.966^{* * *} \\
(0.122)\end{array}$ & $\begin{array}{c}2.987^{* * *} \\
(0.0537)\end{array}$ \\
\hline High school & $\begin{array}{c}4.880^{* * *} \\
(0.214)\end{array}$ & $\begin{array}{c}5.080^{* * *} \\
(0.126)\end{array}$ & $\begin{array}{c}5.448^{* * *} \\
(0.240)\end{array}$ & $\begin{array}{c}5.144^{* * *} \\
(0.206)\end{array}$ & $\begin{array}{c}5.150^{* * *} \\
(0.0893)\end{array}$ \\
\hline Technical or higher & $\begin{array}{c}6.075^{* * *} \\
(0.298)\end{array}$ & $\begin{array}{c}5.955^{* * *} \\
(0.125)\end{array}$ & $\begin{array}{c}6.685^{* * * *} \\
(0.286)\end{array}$ & $\begin{array}{c}5.824^{* * *} \\
(0.409)\end{array}$ & $\begin{array}{c}6.201^{* * *} \\
(0.102)\end{array}$ \\
\hline Constant & $\begin{array}{c}5.683^{* * *} \\
(0.0831)\end{array}$ & $\begin{array}{c}6.737^{* * *} \\
(0.0564)\end{array}$ & $\begin{array}{c}6.595^{* * *} \\
(0.0857)\end{array}$ & $\begin{array}{c}6.393^{* * *} \\
(0.0735)\end{array}$ & $\begin{array}{c}6.438^{* * *} \\
(0.0359)\end{array}$ \\
\hline Observations & 5.555 & 14.466 & 4.840 & 6.270 & 31.131 \\
\hline Adjusted $R^{2}$ & 0,166 & 0,194 & 0,193 & 0,151 & 0,187 \\
\hline \multicolumn{6}{|c|}{$\begin{array}{l}\text { Source: Authors' calculations based on Living Standards Surveys of } 1997,2003,2008 \text {, and } 2010 . \\
\text { Note: } * \text { coefficient is statistically significant at } 10 \% \text { level; } * * \text { at } 5 \% \text { level; } * * * \text { at } 1 \% \text { level; no asterisk: } \\
\text { the coefficient is not different from zero with statistical significance. }\end{array}$} \\
\hline
\end{tabular}

The interactions of parents' education and middle-class entrepreneurs' dummy variables are not always significant. They are negative and significant in the 2003 and 2010 regressions however, and when the data of all four surveys are pooled together. The resulting lower correlation in the case of middle-class entrepreneurs suggests that their educational attainment is less explained by their parents' educational attainment than is the case with lower-class individuals, but more than is the case with individuals belonging to the upper class.

Progress in terms of educational attainment between 1997 and 2010 is probably a result of government policies aimed at reaching previously 
Table 6. Social mobility regressions 2

\begin{tabular}{|c|c|c|c|c|c|}
\hline $\begin{array}{l}\text { Dependent variable: } \\
\text { Year of schooling } \\
(i t)\end{array}$ & $\begin{array}{c}1997 \\
(1)\end{array}$ & $\begin{array}{c}2003 \\
(2)\end{array}$ & $\begin{array}{c}2008 \\
(3)\end{array}$ & $\begin{array}{c}2010 \\
(4)\end{array}$ & $\begin{array}{c}\text { Pooled } \\
\text { data } \\
(5)\end{array}$ \\
\hline \multicolumn{6}{|l|}{ Parents' schooling attainment } \\
\hline Elementary & $\begin{array}{c}2.957^{* * *} \\
(0.123)\end{array}$ & $\begin{array}{l}2.968^{* * *} \\
(0.0803)\end{array}$ & $\begin{array}{c}3.010^{* * *} \\
(0.139)\end{array}$ & $\begin{array}{c}2,980^{* * *} \\
(0.123)\end{array}$ & $\begin{array}{c}2.993^{* * *} \\
(0.0542)\end{array}$ \\
\hline High school & $\begin{array}{c}4.861^{* * *} \\
(0.219)\end{array}$ & $\begin{array}{c}5.079 * * * \\
(0.130)\end{array}$ & $\begin{array}{c}5.422^{* * *} \\
(0.246)\end{array}$ & $\begin{array}{c}5.091^{* * *} \\
(0.210)\end{array}$ & $\begin{array}{c}5.132^{* * *} \\
(0.0915)\end{array}$ \\
\hline Technical or higher & $\begin{array}{c}5.910^{* * *} \\
(0.308)\end{array}$ & $\begin{array}{c}5.943^{* * *} \\
(0.128)\end{array}$ & $\begin{array}{c}6.748^{* * *} \\
(0.299)\end{array}$ & $\begin{array}{c}5.934^{* * *} \\
(0.413)\end{array}$ & $\begin{array}{c}6.187^{* * *} \\
(0.105)\end{array}$ \\
\hline $\begin{array}{l}\text { Dummy }=1 \text { if middle-class } \\
\text { entrepreneur }\end{array}$ & $\begin{array}{c}2.467^{* * * *} \\
(0.710)\end{array}$ & $\begin{array}{c}2.954^{* * *} \\
(0.420)\end{array}$ & $\begin{array}{c}1.663^{* * *} \\
(0.613)\end{array}$ & $\begin{array}{c}3.385^{* * *} \\
(0.548)\end{array}$ & $\begin{array}{c}2.775^{* * *} \\
(0.271)\end{array}$ \\
\hline $\begin{array}{l}\text { Dummy }=1 \text { if upper-class } \\
\text { entrepreneur }\end{array}$ & $\begin{array}{c}4.023^{* * *} \\
(2.443)\end{array}$ & $\begin{array}{c}4.780^{* * *} \\
(1.286)\end{array}$ & $\begin{array}{c}3.948^{* * *} \\
(1.772)\end{array}$ & $\begin{array}{c}5.759^{* * *} \\
(1.133)\end{array}$ & $\begin{array}{c}5.024^{* * *} \\
(0.729)\end{array}$ \\
\hline $\begin{array}{l}\text { Dummy }=1 \text { if middle-class } \\
\text { entrepreneur x Elementary }\end{array}$ & $\begin{array}{c}-1.460 * * * \\
(0.878)\end{array}$ & $\begin{array}{c}-1.513^{* * *} \\
(0.536)\end{array}$ & $\begin{array}{c}-0.634^{* * *} \\
(0.878)\end{array}$ & $\begin{array}{c}-2.036^{* * *} \\
(0.863)\end{array}$ & $\begin{array}{c}-1.501^{* * *} \\
(0.362)\end{array}$ \\
\hline $\begin{array}{l}\text { Dummy }=1 \text { if middle-class } \\
\text { entrepreneur x High school }\end{array}$ & $\begin{array}{c}-2.257^{* * *} \\
(1.182)\end{array}$ & $\begin{array}{c}-2.086^{* * *} \\
(0.660)\end{array}$ & $\begin{array}{c}-1.193^{* * *} \\
(1.587)\end{array}$ & $\begin{array}{c}-1.672^{* * *} \\
(1.185)\end{array}$ & $\begin{array}{c}-1.931^{* * *} \\
(0.482)\end{array}$ \\
\hline $\begin{array}{l}\text { Dummy }=1 \text { if middle-class } \\
\text { entrepreneur } \mathrm{x} \text { Technical or higher }\end{array}$ & $\begin{array}{c}0.279^{* * *} \\
(1.543)\end{array}$ & $\begin{array}{c}-1.681^{* * *} \\
(0.721)\end{array}$ & $\begin{array}{c}-1.263^{* * *} \\
(1.529)\end{array}$ & $\begin{array}{c}-5.626^{* * *} \\
(2.618)\end{array}$ & $\begin{array}{c}-1.570^{* * *} \\
(0.567)\end{array}$ \\
\hline $\begin{array}{l}\text { Dummy }=1 \text { if upper-class } \\
\text { entrepreneur x Elementary }\end{array}$ & $\begin{array}{c}-0.124^{* * *} \\
(2.733)\end{array}$ & $\begin{array}{c}-1.831^{* * *} \\
(1.576)\end{array}$ & $\begin{array}{c}-1.368^{* * *} \\
(2.120)\end{array}$ & $\begin{array}{c}-1.713^{* * *} \\
(1.485)\end{array}$ & $\begin{array}{c}-1.682^{* * *} \\
(0.896)\end{array}$ \\
\hline $\begin{array}{l}\text { Dummy }=1 \text { if upper-class } \\
\text { entrepreneur x High school }\end{array}$ & $\begin{array}{c}0.473^{* * *} \\
(3.096)\end{array}$ & $\begin{array}{c}-3.323^{* * *} \\
(1.620)\end{array}$ & $\begin{array}{c}-2.307^{* * *} \\
(2.154)\end{array}$ & $\begin{array}{c}-2.241^{* * *} \\
(1.708)\end{array}$ & $\begin{array}{c}-2.613^{* * *} \\
(0.958)\end{array}$ \\
\hline $\begin{array}{l}\text { Dummy }=1 \text { if upper-class } \\
\text { entrepreneur } x \text { Technical or higher }\end{array}$ & $\begin{array}{c}-1.327^{* * *} \\
(3.245)\end{array}$ & $\begin{array}{c}-3.816^{* * *} \\
(1.446)\end{array}$ & $\begin{array}{l}-4.605^{* * *} \\
(2.137)\end{array}$ & $\begin{array}{c}-2.000^{* * *} \\
(4.540)\end{array}$ & $\begin{array}{c}-4.136^{* * *} \\
(0.917)\end{array}$ \\
\hline Constant & $\begin{array}{c}5.644^{* * *} \\
(0.0835)\end{array}$ & $\begin{array}{c}6.674^{* * *} \\
(0.0568)\end{array}$ & $\begin{array}{c}6.552^{* * *} \\
(0.0865)\end{array}$ & $\begin{array}{c}6.308^{* * *} \\
(0.0739)\end{array}$ & $\begin{array}{c}6.376^{* * *} \\
(0.0361)\end{array}$ \\
\hline Observations & 5.554 & 14.466 & 4.840 & 6.270 & 31.130 \\
\hline Adjusted $R^{2}$ & 0,170 & 0,199 & 0,195 & 0,163 & 0,193 \\
\hline
\end{tabular}

Source: Authors' calculations based on Living Standards Surveys of 1997, 2003, 2008 and 2010.

Note: ${ }^{*}=$ coefficient is statistically significant at $10 \%$ level; ** at $5 \%$ level; ${ }^{* *}$ at $1 \%$ level; no asterisk: the coefficient is not different from zero with statistical significance.

excluded populations. Figure 1 shows the schooling evolution of four age groups over this period, once again considering entrepreneurs and employees separately. The progress in average years of schooling of individuals in the lower class is impressive. Not only are the younger age groups achieving higher education levels than the older age groups at every point in time observed, but also the least-educated age groups are increasingly more educated than they were in the past. In contrast, the evolution of average schooling in the middle class is much flatter. 
Figure 1. Years of schooling by age group, 1997-2010

A. Lower-class entrepreneurs

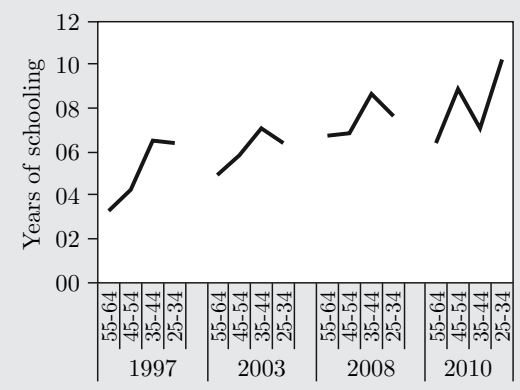

B. Middle-class entrepreneurs

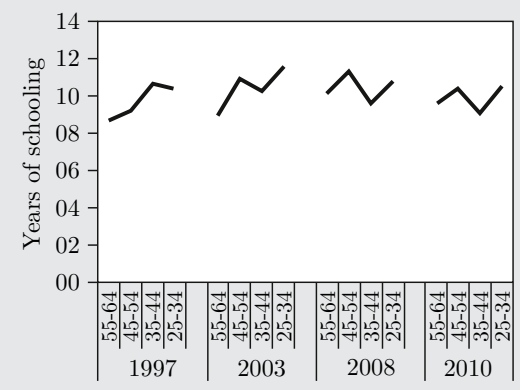

A. Lower-class employees

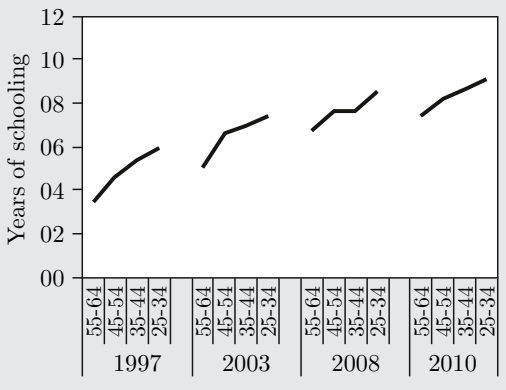

B. Middle-class employees

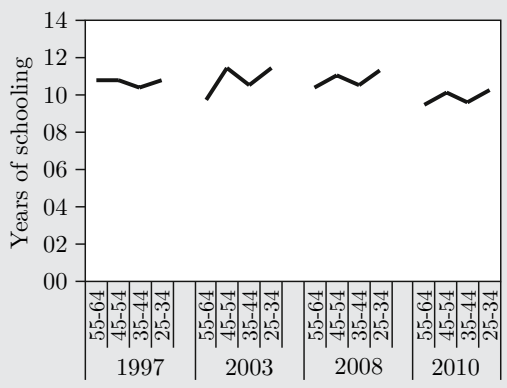

Source: Authors' calculations based on Living Standards Survey 2010.

\section{INTRA-GENERATIONAL MOBILITY}

Unfortunately there are no panel data available that would allow us to estimate a model of social mobility relating an individual's income to his or her parents' income in the past or to parents' wealth. Using pseudopanel techniques, however, we are able to explore intra-generational earnings dynamics: that is, how much individuals' earnings today are determined by their earnings in the past.

Pseudo-panel estimation techniques involve using cohorts of individuals with common characteristics from repeated cross-sections and analyzing the observations of cohort averages as if they were observations of individuals observed in consecutive time periods (as originally suggested by Deaton (1985)). 
Following the literature on pseudo panels, we start by estimating a basic model of absolute mobility:

$$
\bar{Y}_{c(t),(t)}=\alpha+\beta \bar{Y}_{c(t-1),(t-1)}+\varepsilon_{c(t),(t)}
$$

where $\bar{Y}_{c(t),(t)}$ is the cohort's average labor income at time $t$ and $\bar{Y}_{c(t-1),(t-1)}$ is the cohort's average labor income at time $t-1$. Since this equation does not control for individual characteristics, it captures the importance of current income in determining the evolution of its future values.

We then estimate a second equation in which we interact the cohorts' average labor income at time $t-1$ with the share of individuals who are entrepreneurs (calculated over all working individuals), $M C E$, in order to capture any differential impact on income mobility from entrepreneurship:

$$
\bar{Y}_{c(t),(t)}=\alpha+\beta_{1} \bar{Y}_{c(t-1),(t-1)}+\beta_{2} M C E+\beta_{3} Y_{c(t-1),(t-1)} M C E+\varepsilon_{c(t),(t)}
$$

We also estimate an additional model specification including interactions of the cohorts' average labor income at time $t-1$ with a dummy equal to 1 if the cohort is a female cohort. In a second set of regressions, we replace the cohorts' average labor income (at times $t$ and $t-1$ ) with the ratio of the cohorts' average labor income to their median labor income. This set of regressions is designed to assess relative mobility. The whole exercise is then redone, substituting the individual's labor income with his/her household's per capita income. In this case, we restrict the sample to working individuals who are the main providers of their household's income, in order not to introduce distortions from households in which entrepreneurs coincide with other types of workers (who may be driving the household's per capita income).

We experimented with alternative cohort definitions in order to understand the effect of including different time-invariant individual characteristics (resulting in synthetic panels of varying sizes and cohorts encompassing different numbers of observations). Because this does not seem to alter our main findings, we discuss the results obtained from the cohorts more broadly defined, by birth year (with each cohort containing five years), and gender. This partition results in a total of 93 observations spread over four years $\left(1997,2003,2008\right.$, and 2010). ${ }^{12}$ 


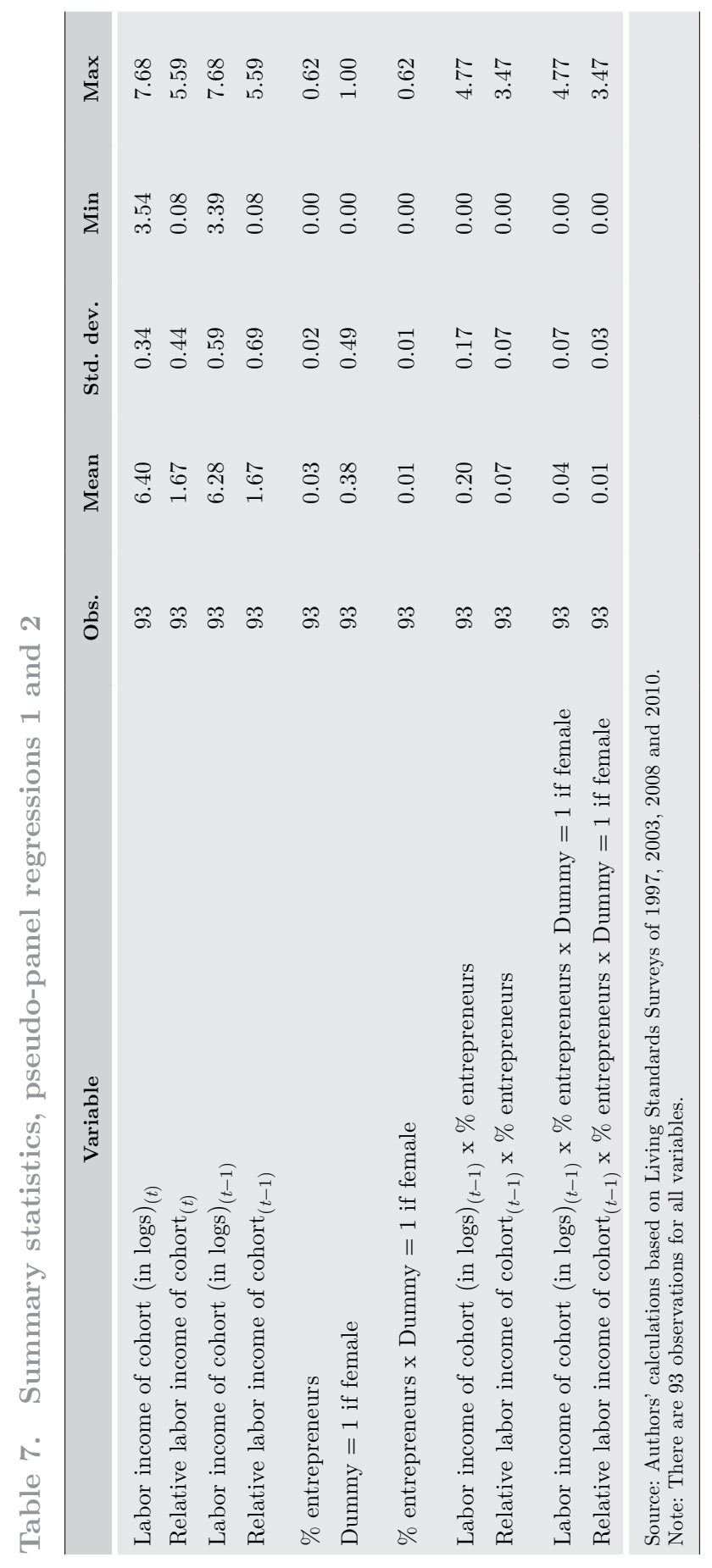


The results of the regressions based on labor earnings ${ }^{13}$ are presented in tables 8 and 9. They show that entrepreneurship has a positive impact on both absolute and relative mobility. While the overall intra-generational absolute income persistence parameter obtained is 0.51 , the parameter for entrepreneurs is much lower: 0.27 . Similarly, while the overall intra-generational relative persistence parameter is 0.50 , the relative persistence parameter for entrepreneurs is $0.34 .{ }^{14}$

Table 8. Income persistence, pseudo-panel regressions 1

\begin{tabular}{|c|c|c|c|c|}
\hline \multirow{2}{*}{$\begin{array}{l}\text { Dependent } \\
\text { variable: } Y_{(c, t)}\end{array}$} & \multicolumn{2}{|c|}{$\begin{array}{l}\text { Labor income per capita } \\
\text { (in logs) }\end{array}$} & \multicolumn{2}{|c|}{$\begin{array}{l}\text { Labor income per capita/ } \\
\text { Median labor income per capita }\end{array}$} \\
\hline & (1) & (2) & (3) & (4) \\
\hline$Y_{(c, t-1)}$ & $\begin{array}{l}0.500^{* *} \\
{[0.032]}\end{array}$ & $\begin{array}{l}0.507^{* *} \\
{[0.041]}\end{array}$ & $\begin{array}{l}0.537^{* *} \\
{[0.037]}\end{array}$ & $\begin{array}{l}0.499^{* *} \\
{[0.064]}\end{array}$ \\
\hline$\%$ entrepreneurs & & $\begin{array}{l}45.570^{* *} \\
{[12.940]}\end{array}$ & & $\begin{array}{l}14.140^{* *} \\
{[3.130]}\end{array}$ \\
\hline $\begin{array}{l}Y_{(c, t-1)} \times \% \\
\text { entrepreneurs }\end{array}$ & & $\begin{array}{c}-6.672^{* *} \\
{[1.883]}\end{array}$ & & $\begin{array}{c}-4.516^{* *} \\
{[1.079]}\end{array}$ \\
\hline Constant & $\begin{array}{l}3.261^{* *} \\
{[0.204]}\end{array}$ & $\begin{array}{l}3.168^{* *} \\
{[0.245]}\end{array}$ & $\begin{array}{l}0.767^{* *} \\
{[0.066]}\end{array}$ & $\begin{array}{l}0.690^{* *} \\
{[0.077]}\end{array}$ \\
\hline Observations & 93 & 93 & 93 & 93 \\
\hline Adjusted $R^{2}$ & 0.722 & 0.751 & 0.695 & 0.748 \\
\hline
\end{tabular}

These results are sustained when interactions of the share of entrepreneurs in the cohort and a dummy variable indicating whether it is a female cohort are included in the estimation. In this case, the absolute persistence parameter for entrepreneurs is even lower, 0.23 , and their relative persistence parameter is 0.36 .

Table 10 presents the summary statistics for the pseudo-panel database constructed using per-capita income. Tables 11 and 12 present the results for these pseudo-panel regressions ${ }^{15}$. Recall that

13. Labor earnings or income denotes either wages or dividends received.

14. Entrepreneurship is riskier, even after businesses are started, so wildly varying incomes will also appear to be mobility in the sense of a lower correlation across time. The pseudo-panel approach may be mitigating this somewhat, but this is still worth noting.

15. In this case, estimation is done over 89 cohort observations. 
Table 9. Income persistence, pseudo-panel regressions 2

\begin{tabular}{|c|c|c|}
\hline Dependent variable: $Y_{(c, t)}$ & $\begin{array}{c}\text { Income per } \\
\text { capita (in logs) } \\
\text { (1) }\end{array}$ & $\begin{array}{l}\text { Income per capita/ } \\
\text { Median income per capita } \\
(2)\end{array}$ \\
\hline$Y_{(c, t-1)}$ & $\begin{array}{c}0.550^{* *} \\
{[0.051]}\end{array}$ & $\begin{array}{c}0.661^{* *} \\
{[0.085]}\end{array}$ \\
\hline$\%$ entrepreneurs $(c, t-1)$ & $\begin{array}{l}68.690^{* *} \\
{[15.570]}\end{array}$ & $\begin{array}{c}20.540 * * \\
{[3.717]}\end{array}$ \\
\hline Dummy $=1$ if female & $\begin{array}{c}0.089 \\
{[0.466]}\end{array}$ & $\begin{array}{c}0.130 \\
{[0.152]}\end{array}$ \\
\hline $\begin{array}{l}\% \text { entrepreneurs }(c, t-1) \\
\mathrm{x} \text { Dummy }=1 \text { if female }\end{array}$ & $\begin{array}{c}-51.330^{*} \\
{[24.360]}\end{array}$ & $\begin{array}{c}-19.230^{* *} \\
{[6.422]}\end{array}$ \\
\hline$Y_{(c, t-1)} \times \%$ entrepreneurs $(c, t-1)$ & $\begin{array}{c}-10.280^{* *} \\
{[2.274]}\end{array}$ & $\begin{array}{c}-8.881^{* *} \\
{[1.577]}\end{array}$ \\
\hline$Y_{(c, t-1)} \times$ Dummy $=1$ if female & $\begin{array}{l}-0.020 \\
{[0.080]}\end{array}$ & $\begin{array}{l}-0.142 \\
{[0.128]}\end{array}$ \\
\hline $\begin{array}{l}Y_{(c, t-1)} \times \% \text { entrepreneurs }(c, t-1) \\
\times \text { Dummy }=1 \text { if female }\end{array}$ & $\begin{array}{l}7.095+ \\
{[3.570]}\end{array}$ & $\begin{array}{l}7.273^{* *} \\
{[2.076]}\end{array}$ \\
\hline Constant & $\begin{array}{c}2.972^{* *} \\
{[0.295]}\end{array}$ & $\begin{array}{c}0.580^{* *} \\
{[0.103]}\end{array}$ \\
\hline Observations & 93 & 93 \\
\hline Adjusted $R^{2}$ & 0.790 & 0.800 \\
\hline
\end{tabular}

Source: Authors' calculations based on Living Standards Surveys of 1997, 2003, 2008 and 2010. Note: ${ }^{*}=$ coefficient is statistically significant at $10 \%$ level; ${ }^{* *}$ at $5 \%$ level; ${ }^{* * *}$ at $1 \%$ level; no asterisk: the coefficient is not different from zero with statistical significance.

in this case the sample is restricted only to working individuals who are their household's main income providers. The overall absolute income persistence parameter in this case is lower, 0.34, indicating higher mobility among this group of individuals. Once again, absolute mobility is found to be above average for entrepreneurs (persistence parameter of 0.24 ). Relative mobility results differ from the previous results, however. In this case, entrepreneurs do not appear to have higher relative mobility than other individuals. Also, the inclusion of interactions with the female dummy variable turns most results insignificant (except the overall absolute persistence parameter).

\section{MIDDLE-CLASS ENTREPRENEURS VIEWED THROUGH THEIR SECTORS OF CHOICE}

As in other Latin American countries, entrepreneurship in not very widespread in Colombia and tends to be more prevalent among the wealthier segments of the population. In 2010, there were 237,000 


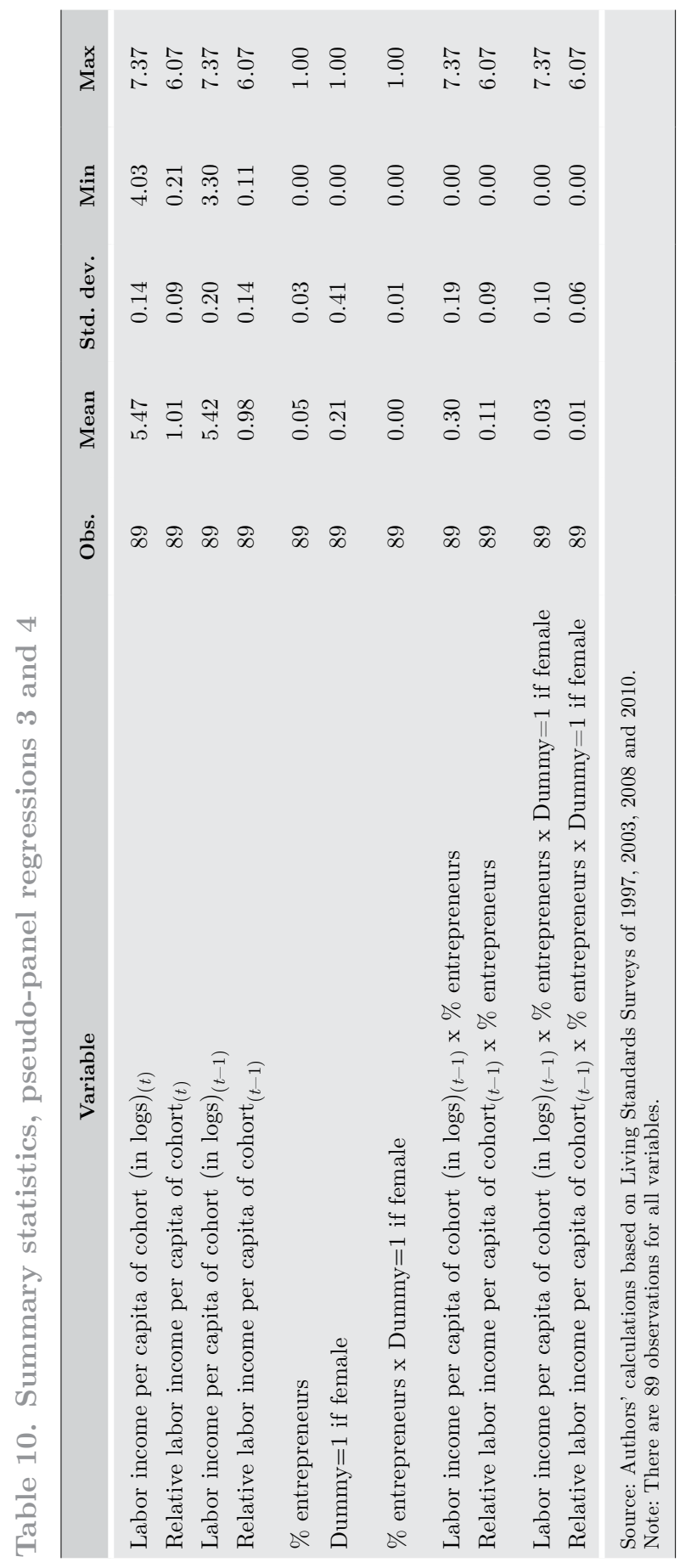


Table 11. Income persistence, pseudo-panel regressions 3

\begin{tabular}{|c|c|c|c|c|}
\hline \multirow{2}{*}{$\begin{array}{l}\text { Dependent } \\
\text { variable: } Y_{(c, t)}\end{array}$} & \multicolumn{2}{|c|}{$\begin{array}{l}\text { Labor income per capita } \\
\text { (in logs) }\end{array}$} & \multicolumn{2}{|c|}{$\begin{array}{l}\text { Labor income per capita/ } \\
\text { Median labor income per capita }\end{array}$} \\
\hline & (1) & (2) & (3) & (4) \\
\hline$Y_{(c, t-1)}$ & $\begin{array}{c}0.336^{* *} \\
{[0.057]}\end{array}$ & $\begin{array}{c}0.361^{* *} \\
{[0.078]}\end{array}$ & $\begin{array}{c}0.503^{* *} \\
{[0.059]}\end{array}$ & $\begin{array}{c}0.433^{* *} \\
{[0.083]}\end{array}$ \\
\hline$\%$ entrepreneurs & & $\begin{array}{c}15.570+ \\
{[9.006]}\end{array}$ & & $\begin{array}{l}5.871^{*} \\
{[2.697]}\end{array}$ \\
\hline $\begin{array}{l}Y_{(c, t-1)} \times \% \\
\text { entrepreneurs }\end{array}$ & & $\begin{array}{c}-2.391+ \\
{[1.415]}\end{array}$ & & $\begin{array}{l}-1.172 \\
{[0.838]}\end{array}$ \\
\hline Constant & $\begin{array}{c}4.079 * * \\
{[0.348]}\end{array}$ & $\begin{array}{c}3.892^{* *} \\
{[0.453]}\end{array}$ & $\begin{array}{l}0.983^{* *} \\
{[0.121]}\end{array}$ & $\begin{array}{c}0.959^{* *} \\
{[0.136]}\end{array}$ \\
\hline Observations & 89 & 89 & 89 & 89 \\
\hline Adjusted $R^{2}$ & 0.275 & 0.284 & 0.444 & 0.463 \\
\hline \multicolumn{5}{|c|}{$\begin{array}{l}\text { Source: Authors' calculations based on Living Standards Surveys of } 1997,2003,2008 \text { and } 2010 . \\
\text { Note: } * \text { = coefficient is statistically significant at } 10 \% \text { level; } * * \text { at } 5 \% \text { level; *** at } 1 \text { percent level; no } \\
\text { asterisk: the coefficient is not different from zero with statistical significance. }\end{array}$} \\
\hline
\end{tabular}

Table 12. Income persistence, pseudo-panel regressions 4

\begin{tabular}{|c|c|c|}
\hline \multirow{2}{*}{ Dependent variable: $Y_{(c, t)}$} & $\begin{array}{l}\text { Income per capita } \\
\text { (in logs) }\end{array}$ & $\begin{array}{c}\text { Income per capita/ } \\
\text { Median income per capita }\end{array}$ \\
\hline & (1) & (2) \\
\hline$Y_{(c, t-1)}$ & $\begin{array}{l}0.345^{*} \\
{[0.135]}\end{array}$ & $\begin{array}{c}0.295 \\
{[0.184]}\end{array}$ \\
\hline$\%$ entrepreneurs $(c, t-1)$ & $\begin{array}{c}11.630 \\
{[14.870]}\end{array}$ & $\begin{array}{c}0.366 \\
{[4.529]}\end{array}$ \\
\hline Dummy $=1$ if female & $\begin{array}{c}0.237 \\
{[1.109]}\end{array}$ & $\begin{array}{c}0.195 \\
{[0.369]}\end{array}$ \\
\hline $\begin{array}{l}\% \text { entrepreneurs }(c, t-1) \times \text { Dummy } \\
=1 \text { if female }\end{array}$ & $\begin{array}{c}3.821 \\
{[26.420]}\end{array}$ & $\begin{array}{c}-0.830 \\
{[10.390]}\end{array}$ \\
\hline$Y_{(c, t-1)} \times \%$ entrepreneurs $(c, t-1)$ & $\begin{array}{l}-1.715 \\
{[2.456]}\end{array}$ & $\begin{array}{l}2.120 \\
{[2.431]}\end{array}$ \\
\hline$Y_{(c, t-1)} \times$ Dummy $=1$ if female & $\begin{array}{l}-0.034 \\
{[0.191]}\end{array}$ & $\begin{array}{l}-0.006 \\
{[0.231]}\end{array}$ \\
\hline $\begin{array}{l}Y_{(c, t-1)} \times \% \text { entrepreneurs }(c, t-1) \\
\mathrm{x} \text { Dummy }=1 \text { if female }\end{array}$ & $\begin{array}{l}-0.736 \\
{[3.924]}\end{array}$ & $\begin{array}{l}-2.571 \\
{[2.942]}\end{array}$ \\
\hline Constant & $\begin{array}{l}3.975^{* *} \\
{[0.764]}\end{array}$ & $\begin{array}{c}1.140 * * \\
{[0.253]}\end{array}$ \\
\hline Observations & 89 & 89 \\
\hline Adjusted $R^{2}$ & 0.253 & 0.473 \\
\hline $\begin{array}{l}\text { Source: Authors' calculations based o } \\
\text { Note: } * \text { = coefficient is statistically sig } \\
\text { the coefficient is not different from ze }\end{array}$ & $\begin{array}{l}\text { tandards Surveys of } 1 \\
10 \% \text { level; } * * \text { at } 5 \% \text { le }\end{array}$ & $\begin{array}{l}997,2003,2008 \text { and } 2010 . \\
\text { vel; } * * * \text { at } 1 \% \text { level; no asterisk: }\end{array}$ \\
\hline
\end{tabular}


middle-class entrepreneurs, representing a very small share of middleclass workers $(5.3 \%)$. Of these, $20 \%$ owned manufacturing businesses and only $7 \%$ owned businesses with more than 10 employees. Therefore, what we set out to do in this section should be taken only as suggestive and our results should not be interpreted as implying causality. We are, however, obtaining results that fit relatively well with our hypothesis that the presence of middle-class entrepreneurs is higher in sectors that are more financially dependent, where activity is less concentrated, and where firms are on average smaller.

To explore to what degree middle-class entrepreneurs are excluded from participating in productive activities requiring large capital expenditures, we use the dataset of the Annual Manufacturing Survey (EAM, for its acronym in Spanish), which is a census of all manufacturing firms with 10 or more employees (this data is also collected by DANE). For the purpose of this research, we use an ISIC 4-digit sector-level panel dataset constructed for the period 2003-2005 from EAM's firmlevel databases, which allows us to follow sector characteristics and performance over time. It contains information on output, employment, labor costs, capital, and financial expenditures and can be combined with official customs records to obtain sector-level data on exports.

Because sectors of activity in the Living Standards Survey are coded only at the ISIC 2-digit sector level, we use DANE's Households Surveys to produce the number of middle-class entrepreneurs by ISIC 4-digit sector, for 2003 to $2005 .{ }^{16}$ We use these data in combination with EAM to estimate a regression of the form:

$$
Y_{i t}=\alpha+\beta_{t}+\lambda X+\varepsilon_{i t}
$$

where $Y_{i t}$ is the number of middle-class entrepreneurs (in logs) in sector $i$ at time $t, \beta_{t}$ is a time dummy, and $X$ is a set of sector-level characteristics.

The results presented in Table 14 suggest a positive relationship between sector size, measured by output, and middle-class entrepreneurship. They also indicate that middle-class entrepreneurship is higher in sectors that are less concentrated (sectors with fewer entry barriers in the form of large-scale economies, resulting in smaller HerfindahlHirshman indexes, HHI) and lower in sectors that export more (measured by the share of firms that export). Similar results are 
Table 13. Summary statistics, presence of middle-class entrepreneurs

\begin{tabular}{lccccc}
\hline Variable & Obs. & Mean & Std. dev. & Min & Max \\
$\begin{array}{l}\text { Number of middle-class } \\
\text { entrepreneurs (in logs) }\end{array}$ & 406 & 3.44 & 3.76 & 0.00 & 11.32 \\
$\begin{array}{l}\text { Output (in logs) } \\
\text { \% of firms that export }\end{array}$ & 406 & 19.02 & 2.01 & 13.37 & 23.60 \\
HHI & 406 & 0.47 & 0.27 & 0.00 & 1.00 \\
$\begin{array}{l}\text { Dummy=1 if ISIC 2-digit sector } \\
\text { is financially dependent }\end{array}$ & 406 & 0.54 & 0.50 & 0.00 & 1.00 \\
$\begin{array}{l}\text { Dummy=1 if sector with low } \\
\text { knowledge content }\end{array}$ & 406 & 0.07 & 0.25 & 0.00 & 1.00 \\
$\begin{array}{l}\text { Dummy=1 if sector with high } \\
\text { knowledge content }\end{array}$ & 406 & 0.17 & 0.37 & 0.00 & 1.00 \\
$\begin{array}{l}\text { Source: Authors' calculations based on DANE Households Surveys and EAM of } 2003,2004 \\
\text { Note: There are } 406 \text { abservations for all variables. }\end{array}$ & & & & \\
\hline
\end{tabular}

obtained when we substitute the HHI concentration measure with the number of establishments (the higher the number of plants, the higher the number of middle-class entrepreneurs) or by the market share of the largest plant (the higher this market share, the lower the number of middle-class entrepreneurs). We also estimate versions of the model including the sector's median firm size by employment. While the coefficient of this variable was negative and significant, its inclusion affected the significance of the variable indicating the extent to which firms in the sector participate as exporters in international markets. Since there seems to be a strong correlation between firm size and exporting activities, we are not showing the version of the model that includes both variables. ${ }^{17}$

To capture the extent to which middle-class entrepreneurship is associated with sectors that are dependent on external financing, we use the Rajan-Zingales measure of financial dependence for ISIC 2-digit sectors. ${ }^{18}$ We define financially dependent sectors as those whose Rajan-Zingales measure is above the median. The coefficient on this variable is negative and significant, indicating that middle-class

17. These results are not included in Table 13 but are available upon request.

18. We are grateful to Luis Catao for sharing his recently updated version of Rajan-Zingales measures, computed as in Rajan and Zingales (1998). 
Table 14. Regressions, presence of middle-class entrepreneurs

\begin{tabular}{|c|c|c|c|c|c|}
\hline $\begin{array}{l}\text { Dependent variable: Number of } \\
\text { middle-class entrepreneurs (in logs) }\end{array}$ & (1) & (2) & (3) & (4) & (5) \\
\hline Output (in logs) & $\begin{array}{l}0.445^{*} \\
{[0.171]}\end{array}$ & $\begin{array}{c}0.604^{* *} \\
{[0.181]}\end{array}$ & $\begin{array}{l}0.413^{*} \\
{[0.177]}\end{array}$ & $\begin{array}{l}0.411^{*} \\
{[0.178]}\end{array}$ & $\begin{array}{l}0.399^{*} \\
{[0.185]}\end{array}$ \\
\hline$\%$ of firms that export & & $\begin{array}{c}-2.557^{* *} \\
{[0.954]}\end{array}$ & $\begin{array}{c}-1.711+ \\
{[1.008]}\end{array}$ & $\begin{array}{c}-1.711+ \\
{[1.009]}\end{array}$ & $\begin{array}{r}-1.853+ \\
{[1.041]}\end{array}$ \\
\hline HHI & & & $\begin{array}{r}-2.839^{*} \\
{[1.395]}\end{array}$ & $\begin{array}{c}-2.837^{*} \\
{[1.396]}\end{array}$ & $\begin{array}{c}-3.088^{*} \\
{[1.471]}\end{array}$ \\
\hline $\begin{array}{l}\text { Dummy }=1 \text { if ISIC } 2 \text {-digit sector is } \\
\text { financially dependent }\end{array}$ & & & & $\begin{array}{c}-0.882^{* *} \\
{[0.159]}\end{array}$ & $\begin{array}{c}-0.885^{* *} \\
{[0.160]}\end{array}$ \\
\hline $\begin{array}{l}\text { Dummy }=1 \text { if sector with low } \\
\text { knowledge content }\end{array}$ & & & & & $\begin{array}{c}1.898^{* *} \\
{[0.330]}\end{array}$ \\
\hline $\begin{array}{l}\text { Dummy }=1 \text { if sector with high } \\
\text { knowledge content }\end{array}$ & & & & & $\begin{array}{c}0.927 \\
{[1.016]}\end{array}$ \\
\hline Constant & -5.262 & $-7.129 *$ & -3.100 & -2.587 & -2.494 \\
\hline Number of observations & {$[3.256]$} & [3.269] & [3.324] & [3.399] & [3.532] \\
\hline \multicolumn{6}{|l|}{ Adjusted $R^{2}$} \\
\hline Number of sectors & 406 & 406 & 406 & 406 & 406 \\
\hline Year dummies & 0.044 & 0.073 & 0.094 & 0.094 & 0.099 \\
\hline 3-digit ISIC sector fixed effect & 74 & 74 & 74 & 74 & 74 \\
\hline
\end{tabular}

entrepreneurs tend to be more concentrated in sectors requiring less external financing (perhaps because middle-class entrepreneurs have lower access to credit, on average). Finally, we use DANE's sector categories of knowledge content ${ }^{19}$ to explore the relationship between middle-class entrepreneurship and sector technological complexity. This classification is then used to construct a dummy variable that equals 1 if the sector belongs in the higher knowledge content category and equals 0 otherwise, and another dummy variable that equals 1 if the sector belongs in the lower knowledge content category and equals 0 otherwise. The coefficient on the former is insignificant. The

19. DANE assigns ISIC 3-digit sectors to three categories according to their knowledge content. Sectors considered to be high in knowledge content are Industrial chemicals; Petroleum refineries; Electrical machinery apparatus, appliances and supplies; and Transport equipment. Sectors in the middle category are Food manufacturing, Beverages, Tobacco, Paper and paper products; and Plastic products. Sectors in the lower category are Metal Ore Mining; Wood and wood and cork products, except furniture; and Furniture and fixtures, except primarily of metal. 
coefficient on the latter is positive and significant, however, indicating that middle-class entrepreneurs are more prevalent in sectors with lower technological complexity.

We are not able to capture a significant relationship between middleclass entrepreneurship and total factor productivity (TFP $)^{20}$. The results reported above are robust to the inclusion of this variable in the estimation.

\section{CONCLUDING REMARKS}

We explore middle-class entrepreneurship from several perspectives, finding that entrepreneurship, defined as business ownership with employees, ${ }^{21}$ is scarce among Colombian workers and is more frequent in the upper class. Middle-class entrepreneurs are better off than middle-class employees of similar characteristics, on average. They are very different from upper-class entrepreneurs, however, in terms of their educational attainment. They are also very different from self-employed workers, who are on average less educated, younger, and more disadvantaged in terms of their outcomes.

We find that entrepreneurship is associated with higher intergenerational income mobility (that is, persistence parameters are lower). Entrepreneurs' outcomes are less positively correlated over time than those of the average worker. We are not able to separate middle-class entrepreneurs from other entrepreneurs in this exercise, however, and we suspect this result is most likely driven by the income dynamics of upper-class entrepreneurs. Also, because we do not observe individuals before they became entrepreneurs, we are unable to establish whether the higher mobility we observe can be specifically attributed to entrepreneurship itself, or whether mobility is even higher, with individuals climbing up in the social ladder as a result of entrepreneurship.

While middle-class entrepreneurs succeed at making a living from their businesses, we are not able to provide empirical evidence supporting the hypothesis that their entrepreneurial activity is an engine for economic growth. On the contrary, our findings suggest that the

20. TFP measures are calculated from micro data, where plant-level TFP is a residual from a standard production function. We use estimates of factor elasticities from Eslava et al. (2006) obtained using instrumental variables methods and EAM data for 1982-1998.

21. Recall that we do not observe individuals over time, so our results refer to individuals already established as entrepreneurs. 
types of businesses they run are low-productivity businesses. For instance, the number of middle-class entrepreneurs is lower in more export-intensive sectors. Also, the fact that middle-class entrepreneurs participate more in sectors that are less concentrated and less dependent on external financing suggests that they face barriers to access to financing, preventing them from making large capital expenditures. We are unable to establish a causal relationship using the available data; that is, we cannot say whether middle-class entrepreneurs are drawn toward sectors of activity with particular characteristics, or rather if those characteristics are a result of a high concentration of middle-class entrepreneurs. Our data do present a set of correlations, however, that cannot be ignored.

Our findings suggest that designing policies to promote middle-class entrepreneurship would be misguided. Instead, policy efforts should be directed toward facilitating social mobility more generally. There is nothing in particular about middle-class entrepreneurs observed in this research that would suggest policies to promote entrepreneurship in this segment of the population should be a priority. 


\section{REFERENCES}

Ardagna, S. and A. Lusardi (2008), "Explaining international differences in entrepreneurship: The role of individual characteristics and regulatory constraints," National Bureau of Economic Research Working Paper No. 14012 .

Banerjee, A.V. and E. Duflo (2008), "What is middle class about the middle classes around the world?" Journal of Economic Perspectives 22(2): 3-28.

Deaton, A. (1985), "Panel data from time series of cross-sections," Journal of Econometrics, 30(1-2): 109-26.

Eslava M., A. Kugler, M. Kugler and J. Haltiwanger (2006), "Plant turnover and structural reforms in Colombia," IMF Staff Papers 53: 58-75.

Evans, D. and B. Jovanovic (1989), "An estimated model of entrepreneurial choice under liquidity constraints," Journal of Political Economy 97(4): 808-27.

Evans, D. and L. Leighton (1989), "Some empirical aspects of entrepreneurship," American Economic Review, 79(3): 519-35.

Gentry, W. and R.G. Hubbard (2004), "Entrepreneurship and household saving," Advances in Economic Analysis and Policy 4(1): 1053.

Hurst, E. and A. Lusardi (2004), "Liquidity constraints, household wealth and entrepreneurship," Journal of Political Economy 112(2): 319-47.

Rajan, R. G. and L. Zingales (1998), "Financial dependence and growth," The American Economic Review 88(3): 559-86. 
